\title{
PENGARUH MOTIVASI, STRESS KERJA DAN LINGKUNGAN KERJA TERHADAP KINERJA GURU YAYASAN PERGURUAN DR WAHIDIN SUDIROHUSODO MEDAN
}

\author{
Ahmad Saputra, Johan \\ Sekolah Tinggi Ilmu Ekonomi IBBI Medan \\ Saputra_damha@yahoo.com
}

\begin{abstract}
ABSTRAK
Motivasi, stres kerja dan lingkungan kerja merupakan variabel yang penting dalam meningkatkan kinerja guru. Dengan adanya motivasi kerja yang tinggi dan lingkungan kerja yang mendukung, maka kinerja yang dihasilkan oleh seorang guru juga akan semakin meningkat. Stres kerja juga memiliki peranan dalam menentukan kinerja yang dihasilkan. Semakin tinggi tingkat stres seorang guru dalam menjalankan tugasnya,maka semakin kurang pula kinerja yang dapat dihasilakan. Tujuan penelitian ini adalah untuk mengetahui adakah pengaruh antara motivasi,stres kerja dan lingkungan kerja terhadap kinerja guru di Dr Wahidin Sudirohusodo Medan baik secara simultan ataupun secara parsial.

Jenis penelitian ini adalah penelitian deskriptif kuantitatif. Teknik pengumpulan data yang digunakan adalah wawancara dan pemberian kuesioner. Metode penelitian yang digunakan dalam penelitian ini adalah análisis deskriptif dan metode análisis kuantitatif. Alat uji yang digunakan untuk menguji hipótesis adalah análisis regresi linear berganda. Populasi dan sampel yang digunakan dalam penelitian ini adalah guru di Yayasan Perguruan Dr Wahidin Sudirohusodo Medan.

Hasil penelitian ini menunjukkan bahwa secara parsial motivasi, Stres kerja dan Lingkungan kerja berpengaruh secara positif dan signifikan terhadap kinerja guru Dr Wahidin Sudirohusodo Medan. Variabel Motivasi, Stres kerja dan lingkungan kerja secara bersama-sama juga berpengaruh positif dan signifikan terhadap kinerja guru Dr Wahidin Sudirohusodo Medan. Kesimpulan penelitian ini adalah motivasi, stres kerja dan lingkungan kerja secara bersama-sama berpengaruh terhadap kinerja guru di Yayasan Perguruan Dr Wahidin Sudirohusodo Medan.
\end{abstract}

Kata Kunci : Motivasi, Stres Kerja, Lingkungan Kerja, Kinerja 


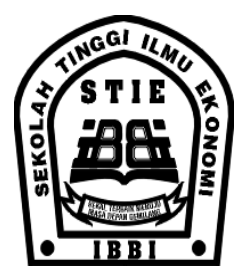

\section{PENDAHULUAN}

Pendidikan merupakan salah satu institusi yang berperan menyiapkan sumber daya manusia. Sekolah merupakan salah satu lembaga alternative pelayanan pendidikan. Untuk mengemban misi, visi, mencapai tujuan, dan menjalankan fungsinya sekolah memerlukan tenaga professional, tata kerja organisasi dan sumber-sumber yang mendukung baik finansial maupun non finansial.

Guru merupakan faktor sentral di dalam sistem pembelajaran terutama di sekolah. Guru juga merupakan salah satu SDM yang berada di sekolah. Kinerja guru dalam dunia pendidikan memang memegang peranan yang sangat penting terutama dalam upaya membentuk watak anak bangsa melalui pengembangan kepribadian dan nilai-nilai akademik yang diinginkan. Oleh karena itu pendidikan memberikan kontribusi yang besar terhadap kemajuan bangsa baik secara individual maupun sosial. Bukan hanya mendobrak kemajuan bangsa tetapi juga dapat meningkatkan status masyarakat menjadi masyarakat yang cerdas yang siap untuk menghadapi dunia luar nantinya. Tanpa adanya kinerja guru yang baik maka akan sulit bagi dunia pendidikan untuk mencapai kemajuan yang diinginkan. Oleh karena itu, sekolah perlu mengamati hal-hal yang dapat mempengaruhi kinerja guru, misalnya faktor motivasi, stres kerja dan lingkungan kerja.

Kinerja guru di Yayasan Perguruan SD Dr Wahidin Sudirohusodo Medan mengalami penurunan. Hal ini dapat dilihat dari beberapa permasalahan yang dihadapi sekolah beberapa tahun terakhir ini. Permasalahan itu seperti semakin banyaknya guru yang melanggar peraturan yang telah diterapkan sekolah seperti dilarang mengkoreksi didalam kelas, menyelesaikan tugastugas administrasi di dalam kelas, menggunakan handphone saat berada didalam kelas selama berlangsungnya kegiatan belajar mengajar, dan guru masih terlihat banyak guru yang duduk saat melakukan pengajaran sehingga kinerja yang dapat diberikan menjadi kurang maksimal selain itu, sekolah juga mendapat complain dari orang tua
ISSN 1858-3199

JURNAL

MANAJEMEN BISNIS

STIE IBBI

murid mengenai sikap atau kesabaran guru dalam menghadapi siswa, kurang tanggapnya guru dalam menghadapi berbagai persoalan yang dihadapi oleh para siswa.

Kinerja guru juga dipengaruhi oleh faktor motivasi kerja. Motivasi adalah keseluruhan daya penggerak atau tenaga pendorong baik yang berasal dari dalam maupun dari luar yang menimbulkan adanya keinginan untuk melakukan suatu kegiatan atau aktifitas dalam menjalakan tugas sebagai guru yang dilaksanakan secara sistematis, berulang-ulang, kontinu dan progresif untuk mencapai tujuan. Seorang guru bila memiliki motivasi kerja tinggi maka akan menghasilkan kinerja yang tinggi pula demikian sebaliknya. Tinggi rendahnya tingkat motivasi sangat berdampak bagi kinerja yang dapat diberikan oleh seorang guru. Dari pengamatan yang telah terlihat beberapa tahun terakhir ini bahwa rendahnya motivasi yang diberikan sekolah terhadap guru masih sangat rendah. Hal ini dapat terlihat dari penghargaan terhadap guru masih sangat rendah. Penghargaan hanya diberikan kepada beberapa guru tertentu saja sehingga masih ada guru yang merasa adanya ketidakadilan.

Selain faktor motivasi masih terdapat faktor lain yang mempengaruhi kinerja guru yaitu stres kerja dan lingkungan kerja. Dalam menjalani profesinya sebagai seorang guru, tidak dapat dipungkiri bahwa tekanan yang dialami oleh seorang guru jauh lebih besar dibandingkan dengan seorang karyawan. Banyaknya pekerjaan yang diberikan oleh pihak sekolah dalam kurun waktu yang kurang tepat juga dapat menjadi indikasi timbulnya stres kerja yang dialami oleh seorang guru. Hal ini terlihat dari kinerja guru Dr. Wahidin Sudirohusodo yang semakin menurun akibat banyak pekerjaan yang dibebankan kepada para guru dalam kurun waktu yang tidak tepat, banyaknya kegiatan yang menyita waktu senggang guru juga menjadi pemicu adanya stres kerja bagi para guru. Selain itu lingkungan kerja yang kurang kondusif seperti berubahnya tata denah tempat duduk siswa, Suasana kelas yang padat dengan keadaan kelas yang panas juga dapat menjadi penyebab turunya kinerja yang dapat diberikan oleh seorang guru.

Sehingga diperoleh beberapa identifikasi masalah yaitu Terdapat indikasi bahwa menurunnya 


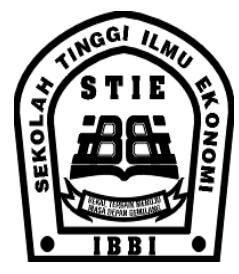

kinerja guru Dr. Wahidin Sudirohusodo dipengaruhi oleh rendahnya motivasi kerja yang diberikan oleh pihak sekolah terhadap guru.Terdapat indikasi bahwa menurunnya kinerja guru Dr. Wahidin Sudirhusodo dipengaruhi oleh tekanan yang dialami oleh guru selama menjalankan tugas-tugas yang diembannya.Kinerja guru Dr. Wahidin Sudirohusodo yang diduga mengalami penurunan juga diduga dipengaruhi oleh adanya ketidak sesuaian penerapan pengajaran yang tertulis di dalam RPP dengan penerapan di lapangan.Terdapat indikasi bahwa stres kerja yang dialami oleh guru Dr. Wahidin Sudirhusodo disebabkan oleh terlalu banyak tugas yang diberikan kepada para guru pada waktu yang kurang tepat.Terdapat indikasi bahwa kinerja guru Dr. Wahidin Sudirohusodo diduga menurun karena dipengaruhi oleh lingkungan kerja yang kurang kondusif.Terdapat indikasi bahwa kinerja guru Dr. Wahidin Sudirohusodo diduga menurun karena dipengaruhi oleh kurangnya kecerdasan emosional yang dimiliki oleh guru dalam mengahadapi para murid.Kinerja guru Dr. Wahidin Sudirohusodo yang diduga mengalami penurunan juga diduga karena dipengaruhi oleh kurang disiplinnya guru dalam menaati peraturan yang telah ditetapkan oleh sekolah.

Adapun tujuan dari penelitian ini adalah Menganalisis pengaruh motivasi terhadap kinerja guru di Yayasan Perguruan Dr. Wahidin Sudirohusodo Medan.Menganalisis pengaruh stres kerja terhadap kinerja guru di Yayasan Perguruan Dr. Wahidin Sudirohusodo Medan. Menganalisis pengaruh lingkungan kerja terhadap kinerja guru di Yayasan Perguruan Dr. Wahidin Sudirohusodo Medan. Menganalisi pengaruh motivasi, stres kerja, dan lingkungan kerja terhadap kinerja guru di Yayasan Perguruan Dr. Wahidin Sudirohusodo Medan.

\section{TINJAUAN LITERATUR}

\section{Definisi Motivasi}

Rivai (2005 : 455) mengemukakan :"Dua hal yang dianggap sebagai dorongan individu yaitu arah perilaku (kerja untuk mencapai tujuan) dan kekuatan perilaku (seberapa kuat usaha individu dalam bekerja)."

Menurut Abraham Maslow mengemukakan bahwa hirarki kebutuhan manusia adalah :

1) Kebutuhan Fisiologis (physiological needs) yaitu kebutuhan yang diperlukan untuk mempertahankan kelangsungan hidup seseorang, seperti makan, minum, udara, perumahan dan lainnya. Dalam organisasi kebutuhan-kebutuhan ini dapat berupa uang, hiburan, program pension, lingkungan kerja yang nyaman.

2) Kebutuhan keselamatan dan keamanan (safety and security needs) yaitu kebutuhan keamanan dari ancaman yakni merasa aman dari ancaman kecelakaan dan melakukan pekerjaan. Dalam organisasi kebutuhan ini dapat berupa keamanan kerja, senioritas, program pemberhentian kerja, uang pesangon.

3) Kebutuhan rasa memiliki (social needs) yaitu kebutuhan akan teman, cinta dan memiliki. Kebutuhan rasa memilki di dalam organisasi dapat berupa kelompok kerja (team work) baik secara formal maupun informal.

4) kebutuhan akan harga diri (esteem needs or status needs ) yaitu, kebutuhan akan penghargaan diri, pengakuan serta penghargaan prestise dari karyawan dan masyarakat lingkungan. Dalam organisasi kebutuhan ini dapat berupa reputasi diri, gelar, dan sebagainya.

5) Kebutuhan akan perwujudan diri (self actualization) yaitu kebutuhan akan aktualisasi diri dengan menggunakan kecakapan, kemampuan, keterampilan dan potensi optimal untuk mencapai prestasi kerja yang sangat memuaskan atau luar biasa yang sulit dicapai orang lain.

\section{Definisi Stres Kerja}

Menurut Soewondo (2003:19), "stres kerja adalah suatu kondisi dimana terdapat suatu atau beberapa faktor di tempat kerja yang berinteraksi dengan pekerja sehingga mengganggu kondisi fisiologis dan perilaku stres kerja akan muncul bila terdapat kesenjangan antara kemampuan individu 


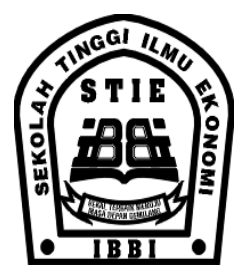

dengan tuntutan-tuntutan dari pekerjannya. Stres merupakan kesenjangan antara kebutuhan individu dengan pemenuhannya dari lingkungan."

Terdapat tiga kategori potensi pemicu stres menurut Robbins (2011:370), yaitu :

1. Faktor-faktor Lingkungan

Selain mempengaruhi desain struktur sebuah organisasi, ketidakpastian lingkungan juga mempengaruhi tingkat sres para karyawan dalam organisasi.

2. Faktor-faktor Organisasi

Tidak sedikit faktor didalam organisasi yang dapat menyebabkan stress. Tekanan untuk menghindari kesalahan atau menyelesaikan tugas dalam waktu yang mepet, beban kerja yang berlebihan, atasan yang selalu menuntut dan tidak peka serta rekan kerja yang tidak menyenangkan adalah beberapa diantaranya.

3. Faktor-faktor pribadi

Seseorang biasanya bekerja sekitar 40 sampai 50 jam seminggu. Tetapi, pengalaman dan masalah yang dihadapi orang dalam waktu 120 jam lebih di luar jam kerja setiap minggunya dapat terbawa ke dunia kerja. Karena itu, kategori terakhir meliputi faktor-faktor dalam kehidupan pribadi karyawan. Faktor-faktor ini terutama adalah masalah keluarga, masalah ekonomi pribadi serta kepribadian dan karakter yang melekat dalam diri seseorang.

Menurut Cox (2005:92) telah mengidentifikasi efek stres yang mungkin muncul. Kategori yang disusun Cox meliputi :

1. Dampak Subyektif (Subjective effect)

Kekhawatiran/kegelisahan, kelesuhan, kebosanan, depresi, keletihan, frustasi, kehilangan kesabaran, perasaan terkucil dan merasa kesepian.

2. Dampak Perilaku (Behavioral effect)

Akibat stres yang berdampak pada perilaku pekerjaan dalam bekerja di antaranya peledakan emosi dan perilaku implusif.

3. Dampak Kognitif (Cognitive effect)

Ketidakmampuan mengambil keputusan yang sehat, daya konsentrasi menurun, kurang perhatian/rentang perhatian pendek, sangat peka terhadap kritik/kecaman dan hambatan mental.
ISSN 1858-3199

JURNAL

MANAJEMEN BISNIS

STIE IBBI

4. Dampak Fisiologis (Physiological effect)

Kecanduan glukosa darah meninggi, denyut jantung dan tekanan darah meningkat, mulut kering, berkeringat, bola mata melebar dan tubuh panas dingin.

5. Dampak Kesehatan (Health effect)

Sakit kepal dan migrant, mimpi buruk, susah tidur, gangguan psikosomatis.

6. Dampak Organisasi (Organization effect) Produktivitas menurun/rendah, terasing dari mitra kerja, ketidakpuasan kerja, menurunnya kekuatan kerja, dan loyalitas terhadap instansi.

\section{Definisi Lingkungan Kerja}

Menurut Sedarmayati (2011:2) mendefenisikan bahwa, "lingkungan kerja maksudnya adalah keseluruhan alat perkakas dan bahan yang dihadapi, lingkungan sekitarnya dimana seseorang bekerja, metode kerjanya, serta pengaturan kerjanya baik sebagai perseorangan maupun sebagai kelompok."

Menurut Sedamayanti (2009:21) menyatakan bahwa secara garis besar jenis lingkungan kerja terbagi menjaddi 2 yakni :

1. Lingkungan kerja fisik

Menurut Sedamaryanti (2009:21) menjelaskan bahwa, "lingkungan kerja fisik adalah semua yang terdapat disekitar tempat kerja yang dapat mempengaruhi pegawai baik secara langsung maupun tidak langsung."

Menurut Sarwono (2005:157) menjelaskan bahwa, "lingkungan kerja fisik adalah tempat kerja pegawai melakukan aktivitasnya.".

2. Lingkungan kerja non-fisik

Menurut Sedarmayanti (2009:21) menyatakan bahwa, "lingkungan kerja non fisik adalah semua keadaan yang terjadi yang berkaitan dengan hubungan kerja, baik dengan atasan maupun dengan sesame rekan kerja ataupun hubungan dengan bawahan."

\section{Definisi Kinerja Guru}

Netawijaya (2006 : 220) secara khusus mendefinisikan kinerja guru sebagai seperangkat perilaku nyata yang ditunjukkan guru pada waktu dia memberikan pembelajaran kepada siswa. 


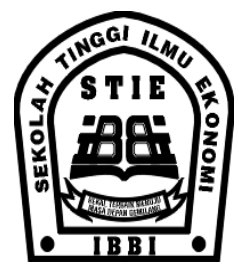

Engkay Karwety (2010), melakukan penelitian dengan judul "Pengaruh Kemempuan Manajerial Kepala Sekolah Dan Faktor Yang Mempengaruhi Motivasi Kerja Terhadap Kinerja Guru SLB Di Kabupaten Subang.” Di dalam jurnal ini kemampuan manjerial kepala sekolah dan motivasi kerja mempunyai pengaruh yang positif dan signifikan terhadap kinerja guru SLB di kabupaten Subang.

I ketut Darmada (2013), melakukan penelitian dengan judul " Kontribusi Kompetensi Manajerial Kepala Sekolah, Iklim Kerja, dan Motivasi Kerja Terhadap Kinerja Guru SMP Negeri Se-kecamatan Mendoyo Kabupaten Jembran." Didalam hasil penelitian dikatakan bahwa terdapat kontribusi yang signifikan anatara Manajerial Kepala Sekolah $\left(\mathrm{X}_{1}\right)$, Iklim Kerja $\left(\mathrm{X}_{2}\right)$, dan Motivasi Kerja $\left(\mathrm{X}_{3}\right)$ terhadap Kinerja Guru (Y) dengan persamaan garis regresi Y.

Fitria Handayani (2011), melakukan penelitian dengan judul " Pengaruh Motivasi dan Lingkungan Kerja Terhadap Kinerja Guru di SMP Negeri 1 Taman." Dari hasil penelitian disimpulkan bahwa variable motivasi dan lingkungan kerja berpengaruh positif dan signifikan terhadap kinerja guru SMP Negeri 1 Taman.

Noviansyah dan Zunaidah (2011). melakukan penelitian dengan judul “ Pengaruh Stres Kerja dan Motivasi Kerja Terhadap Kinerja Karyawan PT. Minanga Ogan Batujaya." Dari kesimpulan hasil penelitian disimpulkan bahwa Variabel Stres Kerja $\left(\mathrm{X}_{1}\right)$ dan Motivasi Kerja $\left(\mathrm{X}_{2}\right)$ secara simultan mempunyai pengaruh yang positif dan signifikan terhadap kinerja Karyawan (Y).

Didalam pelaksanaan kinerja guru atau tenaga kependidikan dapat diukur dengan menggunakan lima aspek yang dapat dijadikan dimensi pengukuran yang disampaikan oleh Mitchell dikutip Mulyasa (2009 : 138) yaitu :

a. Kualitas kerja (Quality of work), berupa mengusai bahan, mengelola proses belajar mengajar, dan mengelola kelas.
ISSN 1858-3199

JURNAL

MANAJEMEN BISNIS

STIE IBBI

b. Ketepatan kerja (Promptness), berupa menggunakan media atau sumber belajar, menguasai landasan pendidikan, merencanakan program pengajaran.

c. Inisiatif (Initiative), berupa memimpin kelas, mengelola interaksi belajar mengajar, melakukan penilaian hasil belajar siswa.

d. Kemampuan (Capability) menggunakan berbagai metode dalam pembelajaran, memahami dan melaksanakan fungsi dan layanan bimbingan penyuluhan.

e. Komunikasi (Communication), memahami dan menyelenggarakan administrasi sekolah dan memahami dan dapat menafsirkan hasil-hasil penelitian untuk peningkatan kualitas pembelajaran.

\section{Penelitian Terdahulu}

Ahirudin (2011), melakukan penelitian dengan judul “ Pengaruh Konflik dan Stres Kerja Terhadap Kinerja Karyawan CV. Bina Nusa Perkasa Bandar Lampung." Hasil penelitian didapat bahwa ada pengaruh yang signifikan antara variabel konflik dan stres kerja terhadap kinerja karyawan CV. Bina Nusa Perkasa Bandar Lampung. 


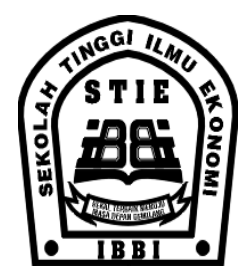

Kerangka Pemikiran

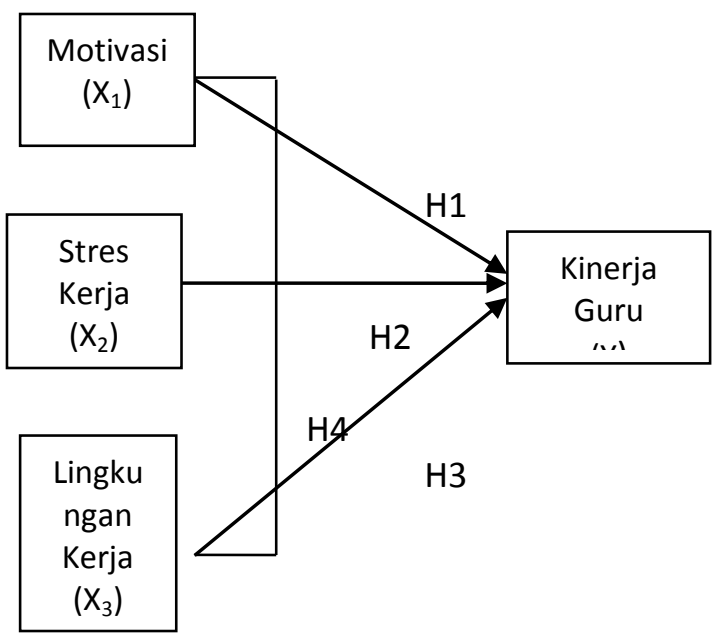

Gambar Kerangka Berpikir

\section{METODE PENELITIAN}

Metode yang digunakan dalam penelitian ini adalah metode deskriptif dan pengujian hipotesis. Penelitian Descriptive dilakukan untuk menjelaskan karakteristik berbagai variabel penelitian dalam situasi tertentu. Penelitian ini dapat pula disebut sebagai penelitian yang menjelaskan fenomena apa adanya. Pengujian Hipotesis Penelitian yang bertujuan untuk menguji hipotesis umumnya menjelaskan karakteristik hubungan-hubungan tertentu atau perbedaan-perbedaan antar kelompok atau idependensi dari dua faktor atau lebih dalam suatu situasi.

Yang menjadi populasi adalah seluruh guru dari Yayasan Perguruan Dr. Wahidin Sudirohusodo Medan yang berjumlah 32 orang. Responden yang akan dijadikan sampel adalah 32 orang. Teknik yang digunakan dalam menetapkan responden adalah total sampling, yaitu pengambilan sampel sebesar populasi yang ada karena jumlah populasi kurang dari 100.
ISSN 1858-3199

JURNAL

MANAJEMEN BISNIS

STIE IBBI

Teknik analisis data yang digunakan adalah analisis regresi linier berganda. Penarikan kesimpulan atas hipotesa dilakukan dengan cara uji $\mathrm{t}$ dengan level signifikansi 5\% dan uji f dengan level signifikansi $5.0 \%$.

\section{HASIL DAN PEMBAHASAN}

Hasil pengujian instrumen dari variabel dapat diketahui bahwa Corrected Item Total Correlation untuk keseluruhan butir pernyataan variabel motivasi, stress kerja, lingkungan kerja dan kinerja guru adalah lebih besar dari koefisien korelasi sebesar 0,30 sebagai pembanding, berarti seluruh butir pernyataan dikatakan valid.

Hasil uji reliabilitas dapat diketahui bahwa cronbach's alpha untuk keseluruhan butir pernyataan motivasi adalah sebesar 0,820 . Variabel stress kerja sebesar 0,895 , lingkungan kerja sebesar 0,822 serta variabel kinerja guru sebesar 0.920. Hasil pengujian dikatakan reliabel karena $r_{\text {alpha }}$ yang lebih besar dari 0,7 .

Berdasarkan tampilan output chart di atas dapat dilihat hasil grafik histogram maupun grafik P-Plot, dimana grafik histogram memberikan pola distribusi yang melenceng ke kanan yang artinya adalah data berdistribusi normal. Selanjutnya pada gambar PPlot terlihat titik-titik tidak mengikuti dan mendekati garis diagonalnya sehingga dapat disimpulkan bahwa model regresi memenuhi asumsi normalitas.

Hasil perhitungan ketiga variabel independent yaitu motivasi, stress kerja dan lingkungan kerja ternyata angka VIF kurang dari 10, sedangkan nilai Tolerance semuanya di atas angka 0,10. Dengan demikian dapat disimpulkan bahwa pada model regresi tersebut tidak terdapat problem multikolinieritas.

Pada hasil gambar terlihat bahwa titik-titik menyebar secara acak, tidak membentuk pola yang jelas. Ini menunjukkan tidak terjadi heteroskedastisitas pada model regresi, sehingga model regresi layak dipakai untuk prediksi pengaruh penilaian kinerja dan disiplin kerja terhadap prestasi kerja karyawan.

Model persamaaan regresi linier berganda adalah $Y=0,136+0,322 X_{1}+0,360 X_{2}+0,317 X_{3}$ 


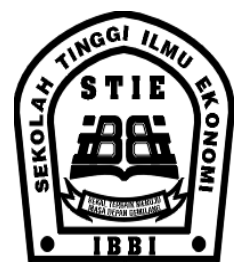

dengan nilai $\mathrm{t}_{\text {hitung }}$ untuk variabel motivasi adalah sebesar 9,440, variabel stress kerja sebesar 10,812 dan lingkungan kerja sebesar 3,53 sedangkan nilai $\mathrm{F}_{\text {hitung }}$ sebesar 157,976. Dan nilai $\mathrm{r}$ korelasi sebesar 0.972 dan $r$ square 0,944 .

\section{Pembahasan}

Pengujian hipotesis secara simultan menunjukkan variabel motivasi, stres kerja dan lingkungan kerja secara bersama-sama mempunyai pengaruh positif dan signifikan terhadap kinerja guru di Dr Wahidin Sudirohusodo dimana $(\alpha)$ sig $=0,000$ $<0,05$ sehubungan dengan analisis regresi berganda dengan melibatkan variabel motivasi, stres kerja dan lingkungan kerja terhadap kinerja guru diperoleh kesimpulan bahwa secara simultan motivasi, stres kerja dan lingkungan kerja berpengaruh terhadap kinerja guru di Yayasan Perguruan Dr Wahidin Sudirohusodo.

Berdasarkan uji $\mathrm{t}$ secara parsial, maka motivasi memiliki pengaruh signifikan terhadap kinerja guru di Dr Wahidin Sudirohusodo Medan, dimana hasil penelitian ini sejalan dengan penelitian terdahulu yang dilakukan oleh Noviansyah dan Zunaidah (2011) dimana didalam penelitiannya tersebut dikatakan bahwa dengan melibatkan karyawan dalam pengambilan keputusan, pekerjaan yang menarik, kelompok dan rekan-rekan kerja yang menyenangkan, kejelasan akan standar keberhasilan, output yang diharapkan, serta bangga terhadap pekerjaan dan perusahaan dapat menjadi faktor pemotivasi kerja bagi karyawan. Dengan demikian hal itu juga dapat menjadi pemotivasi kerja bagi tenaga pendidik seperti guru.

Berdasarkan uji t secara parsial, maka stress kerja memiliki memiliki pengaruh signifikan terhadap kinerja guru di Dr Wahidin Sudirohusodo Medan dimana hasil penelitian ini sejalan dengan hasil penelitian terdahulu yang dilakukan oleh Noviansyah dan Zunaidah (2011) dimana di dalam penelitiannya itu ia mengambil pendapat menurut Kahn, dkk (Munandar, 2001:392), stres yang timbul karena ketidakjelasan peran akhirnya mengarah kepada ketidakpuasan pekerjaan, kurang memiliki
ISSN 1858-3199

JURNAL

MANAJEMEN BISNIS

STIE IBBI

kepercayaan diri, rasa tak berguna, rasa harga diri menurun, depresi, motivasi rendah untuk bekerja, peningkatan tekanan darah, dan kecenderungan untuk meninggalkan pekerjaan. Semakin kuat stres kerja, maka akan memberikan pengaruh yang negatif terhadap kinerjanya. Dengan melihat tingkat stres kerja yang lebih tinggi dibandingkan dengan variabel motivasi dan stres kerja, hal ini sejalan dengan pendapat Margiati (2003 : 78-79) dimana perubahan-perubahan terjadi di tempat kerja merupakan gejala-gejala individu yang mengalami stres antara lain bekerja melewati batas kemampuan, keterlambatan masuk kerja yang sering, ketidakhadiran pekerjaan, kesulitan membuat keputusan, kesalahan yang semborono, kelalaian menyelesaikan pekerjaan, kesulitan berhubungan dengan orang lain. Dari hasil penelitian ini terlihat bahwa stres kerja guru sangat tinggi tetapi hal ini tidakklah menjadi satu hambatan ataupun ketidak mungkinan bagi para guru-guru Dr. Wahidin Sudirohusodo Medan untuk dapat memberikan kinerja yang baik karena dengan melihat tingkat stres kerja yang tinggi maka akan membuat pihak sekolah menjadi termotivasi mengurangi stres kerja tersebut sehingga semua guru Dr Wahidin Sudirohusodo Medan dapat mencapai visi dan misi sekolah yang sudah menjadi tujuan sekolah.

Berdasarkan uji $\mathrm{t}$ secara parsial, maka lingkungan kerja memiliki pengaruh positif dan signifikan terhadap kinerja guru di Dr Wahidin Sudirohusodo Medan dimana hasil penelitian ini sejalan dengan penelitian terdahulu yang dilakukan oleh Fitria Handayani (2011) dimana dari hasil penelitiannya tersebut dikatakan bahwa lingkungan kerja yang baik adalah lingkungan kerja yang dapat mendukung kinerja guru sehingga dapat memberikan konstribusi penting bagi guru dalam mewujudkan tujuan yang telah ditetapkan. Demikian pula dengan hasil penelitian ini, dimana dapat dilihat bahwa lingkungan kerja mempengaruhi kinerja guru Dr. Wahidin Sudirohusodo Medan, maka dari itu sekolah perlu meningkatkan terus lingkungan kerja Dr. Wahidin Sudirohusodo Medan baik secara fisik maupun non fisik karena dengan lingkungan kerja yang baik dan menyenangkan akan sangat membantu para guru untuk dapat mencapai kinerja 


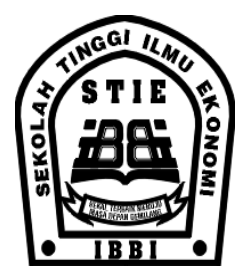

yang jauh lebih baik lagi sebagaimana yang sudah diharapkan oleh sekolah.

\section{KESIMPULAN}

Adapun kesimpulan yang dapat ditarik oleh penulis dari hasil penelitian mengenai pengaruh motivasi, stres kerja dan lingkungan kerja terhadap kinerja guru di Yayasan Perguruan Dr Wahidin Sudirohusodo Medan adalah :

1. Motivasi mempunyai pengaruh yang positif dan signifikan terhadap kinerja guru di Dr Wahidin Sudirohusodo Medan.

2. Stres Kerja mempunyai pengaruh yang positif dan signifikan terhadap kinerja guru di Dr Wahidin Sudirohusodo Medan.

3. Lingkungan Kerja mempunyai pengaruh yang positif dan signifikan terhadap kinerja guru di Dr Wahidin Sudirohusodo Medan.

4. Motivasi, Stres Kerja dan Lingkungan Kerja secara serempak berpengaruh positif dan signifikan terhadap kinerja guru di Yayasan Perguruan Dr Wahidin Sudirohusodo Medan.

\section{REFERENSI}

Arihuddin. 2011. Pengaruh Konflik dan Stres Terhadap Kinerja Karyawan CV. Bina Cipta Nusa Perkasa Bandar Lampung. Jurnal Organisasi dan Manajemen. 1:82-88

Arikunto. 2010. Prosedur Penelitian. Jakarta : Rineka Cipta.

Engkay, Karweti. 2010. Pengaruh Kemampuan Manjerial Kepala Sekolah dan Faktor Yang Mempengaruhi Motivasi Kerja terhadap kinerja Guru SLB di Kabupaten Subang. Jurnal Penelitian Pendidikan. Vol 11 No 2.

Fitria, Handayani. 2011. Pengaruh Motivasi dan Lingkungan Kerja Terhadap Kinerja Guru Di SMP Negeri 1 Taman. Jurnal.

Ghozali, Imam. 2011. Aplikasi Analisis Multivariate Dengan Program SPSS, Edisi Keempat. Penerbit Universitas Diponegoro.

Gomez-Mejia L.R, Balkin, D.B. \&Cardy, R.L., .2001. Manajing Human Resources. USA :Pretince Hall.
ISSN 1858-3199

JURNAL

MANAJEMEN BISNIS

STIE IBBI

I ketut Darmada, Nyoman Dantes, dkk. 2013. Konstribusi Kompetensi Manajeral Kepala Sekolah, Iklim Kerja, dan Motivasi Kerja Terhadap Kinerja Guru SMP Negeri SE Kecamatan Mendoyo Kabupaten Jembrana, Jurnal Pendidikan Dasar Vol 3.

Mangkunegara, AA. Anwar Prabu. 2002. ManajemenSumberDayaManusia

Perusahaan, cetakanpertama. Bandung :RemajaRosadakarya.

Mardiana. 2004. Pengaruh Karakteristik Pekerjaan dan Pengalaman Kerja Terhadap Komitmen Organisasi. Telaah Bisnis, Nomor 2. 2004.

Mathis, R.L.,dan J.H.Jackson. 2002. Manajemen Sumber Daya Manusia, buku 1 dan buku 2. Terjemahan. Salemba Empat, Jakarta.

Mulyasa, E. 2009. Menjadi Kepala Sekolah Profesional. Bandung : PT Remaja Rosadakarya.

Netawijaya, Rochman. 2006. Aktivitas Belajar. Jakarta :Depdiknas.

Nitisemito. 2001. Manajemen Personalia. Edisi kedua Ghalia Indonesia.

Noviansyah dan Zunaidah. 2011. Pengaruh Stres Kerja dan Motivasi Kerja Terhadap Kinerja Karyawan PT. Perkebunan Minang Ogan Baturaja. Jurnal Manajemen dan Bisnis. Vol 9 No.18.

Potter, P.A, Perry, A.G. Kosep , Proses, dan Praktik. Edisi 4, Volume 2. Alih Bahas : Renata Komalasari,dkk. Jakarta : EGC. 2005

Rivai, Veithzal. 2005. Kepemimpinan dan PerilakuOrganisasi. Jakarta : PT Raja GrafindoPersada.

Robbins, Stephen P. 2011. Organization Behavior .New Jersey: Pretice Hall Internasional.

Sedarmayanti. 2009. Sumber Daya Manusia dan Produktivitas Kerja. Bandung : Refika Aksara.

Siswanto, Bedjo. 2005. Manajemen Tenaga Kerja. Bandung : Sinar Baru 